\title{
FINANCIAL MANIPULATION IN SEASONED EQUITY OFFERINGS: EVIDENCE FROM TURKEY
}

\author{
DOI: 10.17261/Pressacademia.2018.936 \\ JEFA- V.5-ISS.3-2018(5)-p.268-287 \\ Mustafa Cikrikci ${ }^{1}$, Mustafa Ozyesil ${ }^{2}$ \\ ${ }^{1}$ Istanbul Aydin University, Istanbul, Turkey. \\ mustafacikrikci@aydin.edu.tr, ORCID: 0000-0002-2805-6079 \\ 2Istanbul Aydin University, Istanbul, Turkey. \\ mozyesil@aydin.edu.tr, ORCID: 0000-0002-4442-7087
}

Date Received: July 7, 2018

Date Accepted: September 14, 2018

To cite this document

Cikrikci, M., Ozyesil, M. (2018). Financial manipulation in seasoned equity offerings: evidence from Turkey. Journal of Economics, Finance and Accounting (JEFA), V.5(3), p.268-287.

Permemant link to this document: http://doi.org/10.17261/Pressacademia.2018.936

Copyright: Published by PressAcademia and limited licenced re-use rights only.

\begin{abstract}
Purpose- This study aims to search whether financial manipulation practices was performed on Seasoned Equity Offerings (seos) by 41 firms in Borsa Istanbul for the 2010-2015 period.

Methodology- Probit analysis and Beneish (1999) model were used in the study. 9 financial ratios were used as independent variables in the probit model in order to find out wheter the firms make manipulation through these ratios. For the purpose of estimating sample firms' tendency for manipulation clustering analysis was also used. Manipulation possibilities were calculated for each firms. Finally based on average index values, firms were grouped as a having high and low manipulation tendency.

Findings- In the model, based on an event study conducted via the bulletins and reports of BIST and SPK, 20 firms were considered as manipulator while the remaining considered as control firms. It was observed that most of manipulation techniques (\%89) were made in order to increase period profit.

Conclusion- It has been confirmed that firms that conducted seos applied the financial manipulation techniques during the analysis period. 3 independent variables include Asset Quality Index, Inventories / Net Sales Index and Total Accruals / Total Assets index were found to be statistically significant in determining whether firms apply financial manipulation. Based on the robustness test, the model's estimating power was calculated as \%70.23. According to the model's reliability test, 11 firms were found as a having high manipulation tendency. This finding refers success rate for estimating manipulator firms in our model is \% $55(11 / 20)$.
\end{abstract}

Keywords: Financial manipulation, seasoned equity offering, beneish model, probit analysis.

JEL Codes: C23, G10, G32

\section{INTRODUCTION}

The accuracy of financial statements reported by the companies to the public can be among the most important factors in the investment decisions of current and potential investors. Therefore, financial statements should include accurate, transparent, appropriate and comparable information (Ulusan, 2008:141). In order to ensure financial information contains accurate, reliable and current values, independent auditing processes are implemented in the world and in Turkey and financial statements are prepared based on international financial reporting standards (IFRS).

However, despite the auditing principles, standards, etc. applied in order to reach the object above mentioned, it can be seen that companies may apply to some wrong, misleading transactions in the financial reports they publish periodically. In the literature, these initiatives of the companies are called financial statement manipulation. Financial manipulation can be defined as a deliberate attempt to deceive and mislead information users especially investors and buyers, through the preparation of financial statements that contain false and misleading information (Rezaee, 2005: 279). Manipulation of financial information can be emerged through some different ways such as earning management practices include (Spathis vd., 2002:510):

- Inflation of the company's assets, sales and profit figures, 
- Reflecting amount of the liabilities, expenses and losses to the financial statements lower than fair value,

- Not providing adequate information about these financial items.

Figures presented on the financial tables may contain incorrect and misleading information due to mistakes and fraudulent transactions. The most important factor that separates the manipulative transactions included in the financials from the errors is whether the transaction that caused the misrepresentation of the financial statements is deliberately made or not.

American Institute of Certified Public Accountants - AICPA, separates incorrect information that causes fraudulent in financial statements, into the two sections as incorrect information due to fraudulent financial reporting and due to mal management of company assets (AICPA, 2002:1721-1722).

According to Association of Certified Fraud Examiners - ACFE; fraud is misrepresenting or deceiving actions that individuals or organizations make although they are aware of the fact that if these actions are performed it will result in an unjust and unfair gain to the individuals, companies or other parties. Therefore, it is necessary to evaluate the errors and fraudulent applications differently. They should not be considered as they have same meanings.

The fraudulent and misleading practices seen on the financial statements can occur as follows (Rezaee, 2005: 279) :

1- Falsification, alteration or manipulation of financial and other supporting documents related to commercial transactions,

2- $\quad$ Transactions, accounts and other important informations that constitute the basis for the preparation of financial statements may contain deliberately wrong and / or misleading figures.

3- Deliberately misapplication or interpretation of accounting standards, principles, policies and methods used to measure, record and report economic events and business transactions,

4- Intentional negligence and insufficient disclosure and presentation related to accounting standards, principles, practices and financial information.

5- $\quad$ Using aggressive accounting techniques with illegal earnings management practices,

6- The manipulation of accounting techniques applied under existing accounting standards, which are very detailed, very easy to manipulate and include some legal gaps that lead firms to hind their real economic performance.

There are three main financial manipulation techniques that companies have implemented using the above-mentioned applications; Earnings Management, Income Smoothing, Creative Accounting Practices (Mulfdord, Comiskey, 2002: 3).

Earnings management can be defined as manipulative process performed by companies on the period profit / loss item in order to be considered less or more profitable.

There is no clear consensus in the literature on the definition of earnings management concept, but there are three different approaches (Beneish, 2001:4) :

- $\quad$ By taking advantage of restrictions seen in the generally accepted accounting principles and in other accounting regulations, publishing desired earning figures with intentional steps taken in the preparation of financial reports.

- $\quad$ For the purpose of earning management, making intervention to the reporting process made to external information users. When we extend this definition a bit further, we find two sub-items of earning management: Timing management and real earnings management that occurs in the form of changing reported earnings or some of its sub-items.

- $\quad$ Earnings management is performed based on implementations made by managers in financial reports when they mislead some stakeholders about the company's real economic performance or adjusting and restructuring financial reports that affect the decisions about the company.

Income smoothing is keeping the earnings of the various periods relatively stable and ensure to avoiding revenues from sharp fluctuations. The main reason lies behind of the stabilization of the profits is the desire of the companies to meet the profitability expectations of the markets and they realize this by reducing the R\&D, marketing and selling, general administrative expenses or postponing or canceling a new project (Acharya, Lambrecht, 2015 : 2534).

There are two basic factors that lead companies to implement income smoothing. (Li, Richie, 2016: 176):

- When the profits become smooth, it will be easier for investors to estimate firms' future earnings.

- Presenting financial figures through smoothing, in fact, means deceiving analysts and other groups interested in the company by manipulating items in the financial reports. Thus it means that managers can take more advantage of managerial incentives. 
Company executives want to keep profit and growth rate balanced and steady in order to ensure sustainability of their positions in the firm and obtain higher financial rights. Because when the firm's growth rate is high and its performance is good, the increase in the company's profitability will not create a big impact on the shareholders, whereas it will have a significiant positive impact when the company has a bad or average performance (Zhang, $2016: 1$ ).

Creative accounting is defined as the fulfillment of the priorities of parties who prepare financial data by making some calculations and publishing them in the financial statements through taking advantage of the gaps and resiliency in the legal regulations. Firms that want to change or hide the undesirable consequences of financial situations and activities (Çelik, 2016:50) usually carry out this practice.

There are two aspects of researching creative accountancy: The first one and in other words the positive one, is an examination of the financial accounting principles and instruments used to describe the macro and microenvironment of an entity and this method specifies how much accounting practices should be changed. The second or negative one is that firms make suspicious and unethical practices even in partial of the financial statements in order to influence investors and gain the trust of stakeholders (Tassadaq, Malik, $2015: 545$ )

Creative accounting techniques may provide some advantages such as decreasing cost of capital, but in the medium and long-term, it will cause loss of investors' confidence about the company. (Çelik, 2016:50).

In the literature, both national and international studies have also showed that firms, which implement seasoned equity offerings, may apply financial manipulation. It has been determined that companies that go to the public again through seasoned equity offerings, may also attempt to mislead investors in financial reports published prior to share issuance in order to maximize issuing revenue. Particularly, firms issuing shares may increase their profitability before the issuance by changing their discretionary accruals published in financial reports (Teoh et al., $1998: 64$ ).

In the next section, a summary of the previous studies in the literature on financial manipulation is given.

\section{LITERATURE REVIEW}

The manipulation of financial statements has been the subject of many researches at both national and international studies. Among the studies, the best known are the models of Healy (1985), DeAngelo (1986), Jones (1991) Beneish performed in 1997, 1999 and 2001 (Küçüksözen, 2004 : 250).

Healy (1985) argued that managers are constantly manipulating financial statements in order to obtain and sustain managerial incentives. He underlined that, for this purpose, the companies used discretionary accruals in their financial statements. In his study, total accruals are calculated by subtracting the cash flow based on the main operations from the net profit. He also obtained discretionary accruals by eliminating non-discretionary ones. Having analyzed the sample of 94 firms between 1930 and 1980, Healy found that firms usually apply period profit increasing techniques first and then apply profits reduction methods since firms cannot apply period profit increasing techniques every year because of particularly auditing process.

DeAngelo (1986) argued that publicly held companies may apply period profit reducing techniques in order to minimize repurchasing costs of stocks in the delisting process. In his study, he examined the sample of 64 firms in the US between 1973 and 1982, and tested whether the firms were making manipulation using the accruals in the financial statements during the stock recall process. However, the results of the analysis in the model did not fully confirm that firms applied to financial manipulation to reduce the period profit. The study may be considered unique in terms of the quality of firms included in the sample because all of the firms consist of companies that have determined a critical decision such as an exit the stock market.

Jones (1991) analyzed 23 firms from 1980 to 1985 in the US, he conducted the test to see wheter firms apply financial manipulation in order to reflect lower period profit through using custom tariffs. He analyzed the manipulative transactions through discretionary accruals as in other studies. In order to calculate the discretionary accruals, he first made a distinction between normal and abnormal accruals in the analysis and assumed that the discretionary accrual was an element of abnormal accruals. Because according to the author the non-discretionary accruals will remain stable or will not change much over the years, therefore the firm will carry out manipulative transactions via the discretionary accruals. If the change in the total accrual year-to-year is negative, it means that the financial manipulation process is performed by using discretionary accruals. In the study, the author calculated the abnormal accrual by subtracting the accrued amount of the current period from the normal accrual, which is the total accrual of the previous period. According to the result of the model, it was concluded that during the analysis period, firms reported low profits in order to benefit from custom tariffs.

Beneish (1997) used the probit model in his study to estimate manipulative transactions in financial statements. Sample firms were divided as manipulators, which performed manipulation practices in the financial statements and control firms that did not. In the analysis covers 1987-1993 period, 64 firms that were regarded to manipulate the financial statements 
by the SEC, the regulator of the capital market in the US, were considered as manipulators. In addition, as control firms, he analyzed 1,989 firms that had a high accrual in financial statements such as manipulator firms but did not involve any fictitious transactions. In his study, he found that manipulator firms performed poorly in medium and long term and their peformance changed seriously from period to period. In the model, 6 variables were used to determine the make-up on the financial statements and 7 variables used to measure the tendency of companies for manipulative processes. These variables are shown in Table 2 and Table 3.

Table 1: Independent Variables Created to Determine Makeup Transactions in Financial Statements

\begin{tabular}{|c|c|c|}
\hline VARIABLE & DESCRIPTION & CALCULATION \\
\hline Trade Receivables Index & $\begin{array}{l}\text { It measures the consistency between the } \\
\text { change in trade receivables and in sales. }\end{array}$ & $\begin{array}{l}\text { Change in Trade Receivables \% } \\
\text { / Change in Sales \% }\end{array}$ \\
\hline Gross Profit Margin Index & $\begin{array}{l}\text { It measures the commercial profitability in } \\
\text { other words the sustainability of the firm. }\end{array}$ & Gross Profit / Sales \\
\hline Active Quality Index & $\begin{array}{l}\text { It measures the risk / ability to convert assets } \\
\text { into money. If the rate is higher than one, it is } \\
\text { an indication that the company is in a tendency } \\
\text { to postpone its costs capitilization. }\end{array}$ & $\begin{array}{l}\text { Fixed Assets (excluding Land, } \\
\text { Facilities and Equipments) / } \\
\text { Total Assets }\end{array}$ \\
\hline Amortisation Index & $\begin{array}{l}\text { The change in depreciation expense is } \\
\text { measured. In this way it is measured whether } \\
\text { the firm slows down these expenses to } \\
\text { increase the period profit. }\end{array}$ & $\begin{array}{l}\text { Current Year Depreciation / } \\
\text { Previous Year Depreciation }\end{array}$ \\
\hline $\begin{array}{l}\text { Marketing } r \text { Sales } \\
\text { Distribution and General } \\
\text { Administrative Expenses } \\
\text { Index }\end{array}$ & $\begin{array}{l}\text { This index analyzes the trends in general } \\
\text { administrative expenses with sales. } \\
\text { Management costs, which are higher than } \\
\text { sales, are considered as an indicator for } \\
\text { manipulative movements. According to } \\
\text { Beneish, there is a positive relationship } \\
\text { between this index and financial manipulation. }\end{array}$ & $\begin{array}{l}\text { (Marketing Sales Distribution } \\
\text { and General Administrative } \\
\text { Expenses on Current Year/ Sale } \\
\text { Revenue on Current Year) / } \\
\text { (Marketing Sales Distribution } \\
\text { and General Administrative } \\
\text { Expenses on Previous Year/ } \\
\text { Sale Revenue on Previous Year) }\end{array}$ \\
\hline $\begin{array}{l}\text { Total Accruals to Total } \\
\text { Assets }\end{array}$ & $\begin{array}{l}\text { This rate measures how much the period profit } \\
\text { is based on the cash assets. The increase in this } \\
\text { ratio indicates a possibility of a financial } \\
\text { manipulation of the company. }\end{array}$ & $\begin{array}{l}\text { Cash Net Operating Capital on } \\
\text { Current Year / Cash Net } \\
\text { Operating Capital on Previous } \\
\text { Year }\end{array}$ \\
\hline
\end{tabular}

Reference : Beneish (1997: 10-12)

Table 2: 7 Variables Developed to Measure Tendency of Manipulative Processes of Firms

\begin{tabular}{|l|l|}
\hline VARIABLE & DESCRIPTION \\
\hline Capital Structure & $\begin{array}{l}\text { It shows the firm's debt and equity composition. If the firm's financing policy is more } \\
\text { in the form of equity, possible increase in firm leverage may be signal for } \\
\text { manipulative process. }\end{array}$ \\
\hline $\begin{array}{l}\text { Historical } \\
\text { Performance }\end{array}$ & $\begin{array}{l}\text { The decrease in the stock price of the company may lead company managers to have } \\
\text { the idea that they will make manipulative operations in financial statements in order } \\
\text { to ensure stock prices peek and thus they may get serious returns. }\end{array}$ \\
\hline Shareholding Structure & $\begin{array}{l}\text { If the owner-manager concept is in question, that is, if the top management of the } \\
\text { firm has a share in the company's capital at the same time, the managers may want to } \\
\text { take advantage of the fluctuations in the share price. }\end{array}$ \\
\hline Quotation Timing & $\begin{array}{l}\text { Firms' IPO time is the period when financial manipulative movements are seen most. } \\
\text { For this reason, there is a high possibility of applying fraudulent transactions in the } \\
\text { financial statements of companies that go to the public. }\end{array}$ \\
\hline Growth in Sales & $\begin{array}{l}\text { If sales fluctuated very harshly up or down compared to the previous period, this may } \\
\text { be regarded as a sign of a manipulation made in the sales item of the company's } \\
\text { income statement. }\end{array}$ \\
\hline $\begin{array}{l}\text { Independent } \\
\text { Company }\end{array}$ & $\begin{array}{l}\text { The auditing techniques, ability to detect mistakes and misrepresentations in the } \\
\text { financial statements and loyalty to ethical values of an independent auditor influence } \\
\text { the potential for manipulative operations of the company. }\end{array}$ \\
\hline
\end{tabular}

Reference: Beneish (1997: 10-12) 
Beneish (1999), has updated his study conducted in 1997. In his new model, he changed variables and sample and also probit analysis. He added Growth in Sales and Change in Firm Leverage variables to the independent variables pool, which includes 6 variables, were created to detect manipulative transaction observed in the financial statement. In this study, 74 firm's data were used instead of 64 firms used in the previous study. First, he separated firms as manipulator and control firms. Then he he revised definition of control firm and described them as firm operating in the same industry as manipulator firms in his updated study.

There are lots studies related financial manipulation on seasoned equity offerings. Table 2 summarizes studies by author and year as follows:

Table 3: International Studies Related Financial Manipulation on Seasoned Equity Offerings

\begin{tabular}{|c|c|c|}
\hline AUTHOR(s) & YEAR & FINDINGS \\
\hline Teoh et al. & 1998 & $\begin{array}{l}\text { They analyzed pre and post issue financial statements of firms in the industrial sector for } \\
\text { the period of } 1976 \text { - 1989.Investors are overly optimistic about the future of the firm } \\
\text { before the issuance because of the aggressive use of Period Profit Increasing Techniques. } \\
\text { The net profitability of firms that issued seasoned equity offerings during the year of } \\
\text { issuance was } 1.69 \% \text { higher than the similar firms, while it was } 1.60 \% \text { and } 0.32 \% \text { less in the } \\
\text { following two years after the issuance. They found out that short-term discretionary accrual } \\
\text { is the most open to managerial manipulation among these four accruals and it is the most } \\
\text { significant determinant of the post-issue financial performance }\end{array}$ \\
\hline Islam et al. & 2002 & $\begin{array}{l}\text { They reviewed the financial statements of } 32 \text { industrial companies for three years before } \\
\text { and after the issuance. The financial performance indicators used in the analysis are; } \\
\text { Operating Income \& Loss Margin, Net Income Margin, Asset and Equity Profitability Ratio, } \\
\text { Operating Income \& Loss Margin / Total Assets ratios. They stated that the companies } \\
\text { made public offering had remarkable operating performance before issuance but there was } \\
\text { a significant decrease in their performance after the issuance. It has been found that the } \\
\text { decline in operating performance seen in the post-issue period is much more severe in } \\
\text { small-scale firms than in the large ones. }\end{array}$ \\
\hline Jo and Kim & 2008 & $\begin{array}{l}\text { Examined financial statements belong to the period include 3-years pre-and post- seasoned } \\
\text { equity offerings and analyzed return of stocks up to } 5 \text { years after the public offering. } \\
\text { They have investigated the relationship between the firms' ethical and public disclosure } \\
\text { practices and the company's long-term performances. They stated that firms that apply } \\
\text { public disclosure practices regularly and become transparency are less tend to apply } \\
\text { financial manipulation and therefore such firms will have a higher long-run performance }\end{array}$ \\
\hline Shu and Chiang & 2014 & $\begin{array}{l}\text { Analyzed the sample that consists of } 463 \text { industrial firms' financial statements prepared the } \\
\text { quarterly basis for last } 5 \text { years by eliminating public and financial institutions. In small firms, } \\
\text { it was determined that the timing effect of seasoned equity offerings was negatively } \\
\text { correlated with the short-term existence of the firm and the positive with long-term } \\
\text { existence. For large firms, it has been determined that earnings management is positively } \\
\text { correlated with short-term wealthy while it is negatively correlated with long-term } \\
\text { prosperity. In firm size - based analysis, they observed that large firms are often tend to } \\
\text { implement earnings management practices, while small-scale firms are more on market } \\
\text { timing. Discretionary accruals for large firms were found to be positively associated with } \\
\text { short-term announcement effect and negatively associated with post-issue profitability. }\end{array}$ \\
\hline Kothari et al. & 2016 & $\begin{array}{l}\text { Have examined the role of manipulation through accruals and real activities in reducing } \\
\text { overvaluation seen in the seasoned equity offerings at the time of the issuance. They name } \\
\text { earning management practices performed through opportunistic reductions particularly in } \\
\text { R\&D, marketing and general administrative expenses as manipulation made based on real } \\
\text { activities. According to the results of the analysis, although they were much more costly } \\
\text { than their long run returns, authors found that firms managers were more inclined to } \\
\text { manipulate financial figures through real activities. }\end{array}$ \\
\hline Fang & 2017 & $\begin{array}{l}\text { Analyzed the existence of real and accrual earnings management applications before and } \\
\text { after seos by using modified Jones (1991) model and Roychowdhury method. According to } \\
\text { results, it was determined that real and accrual earnings management application were } \\
\text { observed both on before and after seos. Also he found out that real and accrual earning } \\
\text { management practies are highly correlated and accrual earning management has a more } \\
\text { impact on short - term peformance of the firms. }\end{array}$ \\
\hline
\end{tabular}




\section{DATA AND METHODOLOGY}

\subsection{Sample Construction}

In this study, it was investigated whether sample that consist of 58 firms conducted seasoned equity offerings between 2010 and 2015 period applied financial manipulation or not. Firms operate in the financial sector and do not have adequate data set were eliminated and thus the number of sample firms included to analysis became 41 . The financial data of the firms included in the sample were obtained from Public Disclosure Plaform (www.kap.org.tr) and statistical analyzes were performed using SPPS program and E - Views 8 version.

In the sample, the breakdown of the firms that their shares traded in markets of the BIST are respectively; 19 firms $(46,34 \%)$ in the main market, 12 firms $(29,27 \%)$ in star market, $4(9,76 \%)$ in developing market and 6 firms in other markets. However, when the sample firms separated based on groups according to BIST classification, we observed that 23 firms (56,10 \%) in A group, 7 firms (17,07 \%) in C group, 6 firms (14,63\%) in B group and 4 firms (9,76\%) in D group.

The index-based breakdown of the sample firms is shown in Table 4.

Table 4: Breakdown of the Firms Based on Index

\begin{tabular}{|l|l|l|}
\hline INDEX & NUMBER OF COMPANIES & $\%$ \\
\hline BIST MAIN & 19 & $46,34 \%$ \\
\hline BIST EMERGING COMPANIES & 4 & $9,76 \%$ \\
\hline EQUITY MARKETS FOR QUALIFIED INVESTORS & 2 & $4,88 \%$ \\
\hline PRE-MARKET TRADING PLATFORM & 2 & $4,88 \%$ \\
\hline WATCHLIST & 2 & $4,88 \%$ \\
\hline BIST STARS & 12 & $\mathbf{2 9 , 2 7 \%}$ \\
\hline GRAND TOTAL & $\mathbf{4 1}$ & $\mathbf{1 0 0 , 0 0 \%}$ \\
\hline
\end{tabular}

Sector-based breakdown of the sample firms is shown in table 5.

Table 5: Breakdown of the Firms by Sector

\begin{tabular}{|l|l|l|}
\hline SECTOR & NUMBER OF COMPANIES & $\%$ \\
\hline FOOD & 6 & $15 \%$ \\
\hline ELECTRICITY & 4 & $10 \%$ \\
\hline HOLDING COMPANY & 3 & $7 \%$ \\
\hline CHEMISTRY & 4 & $10 \%$ \\
\hline MACHINE & 3 & $7 \%$ \\
\hline TEXTILE & 3 & $7 \%$ \\
\hline ALCOHOLIC BEVERAGES & 2 & $5 \%$ \\
\hline CEMENT & 2 & $5 \%$ \\
\hline FERTILIZER & 2 & $5 \%$ \\
\hline CONSTRUCTION & 1 & $2 \%$ \\
\hline FURNITURE & 2 & $5 \%$ \\
\hline RETAIL & 2 & $5 \%$ \\
\hline PACKING & 1 & $2 \%$ \\
\hline PRINTING PRESS & 1 & $2 \%$ \\
\hline AUTOMOTIVE & 1 & $2 \%$ \\
\hline SPORTS & 1 & $2 \%$ \\
\hline
\end{tabular}




\begin{tabular}{|l|l|l|} 
AGRICULTURE & 1 & $2 \%$ \\
\hline TOURISM & 1 & $2 \%$ \\
\hline PUBLISHING & 1 & $2 \%$ \\
\hline GRAND TOTAL & $\mathbf{4 1}$ & $\mathbf{1 0 0 . 0 0 \%}$ \\
\hline
\end{tabular}

When we review the breakdown of the sample firms by sector, we realized that the vast majority of firms are composed of food, electricity, holding, chemical, machinery, textile sectors.

The breakdown of the sample firms on the basis of the equity code is shown in Table 6 .

Table 6: Sample Breakdown Based on Equity Code

\begin{tabular}{|l|l|l|}
\hline EQUITY CODE & NUMBER Of COMPANY & $\%$ \\
\hline- & 1 & $2,44 \%$ \\
\hline A & 23 & $56,10 \%$ \\
\hline B & 6 & $14,63 \%$ \\
\hline C & 7 & $17,07 \%$ \\
\hline D & 4 & $9,76 \%$ \\
\hline GRAND TOTAL & $\mathbf{4 1}$ & $\mathbf{1 0 0 , 0 0} \%$ \\
\hline
\end{tabular}

\subsection{Model}

Financial statements and independent audit reports of sample firms were analyzed, the weekly bulletin of CMB and daily bulletin of BIST related to these firms were also reviewed.

The following methodology has been performed for determining whether firms in the sample are manipulators:

- Firms having qualified or unfavorable independent audit reports,

- Firms having marginal changes in the profitability ratios compared to pre capital increase period,

- Companies that are found to have received a warning, especially punishment, due to their financial table applications as a result of the examinations made by CMB and BIST and published in their reports and bulletins.

These firms were accepted as manipulators and the other companies were analyzed as control companies. As a result of this methodology, 20 firms were accepted as manipulators (49\%) and 21 firms (51\%) were accepted as control firms in the model.

In the study, balance sheets and income statements of the companies covered for the period of 2010-2015 were analyzed. However, 2010 was taken into consideration as base year for the calculation because each company in the sample has a different issuance date. In order to prevent overlapping problem, if firms made two or more issues in the same analysis period, the first issuance was included to analysis while the others excluded from model construction. Years considered as the base year, previous year and following year symbolized as respectively $t, t-1$, and , $t+1$.

The summary financial information for the sample, which is seperated as the manipulator and control companies, is shown in Table 7 below.

Table 7: Summary Financials of Manipulator and Control Firms

\begin{tabular}{|l|r|r|}
\hline SUMMARY FINANCIALS of SAMPLE & \multicolumn{2}{|c|}{ AVERAGE } \\
FIRM TYPE & Manipulator & \multicolumn{1}{c|}{ Control } \\
\hline TOTAL ASSETS & 20.247 .396 .002 & 44.680 .412 .004 \\
NET WORKING CAPITAL & 789.573 .208 & 1.305 .668 .646 \\
TOTAL DEBTS & 13.000 .829 .985 & 24.266 .847 .017 \\
LEVERAGE RATIO & $67,25 \%$ & $71,47 \%$ \\
SALES & 8.967 .556 .007 & 16.516 .046 .603 \\
SALE GROWTH RATE & $-29,45 \%$ & $-30,49 \%$ \\
\hline
\end{tabular}


It can be seen that the manipulator firms in the sample are composed of relatively smaller firms. The average asset size of the manipulator firms is lower than the control firms. Manipulator firms' net working capital is similarly lower compared to control firms. From the viewpoint of total debts item, although the debt amounts of the manipulator firms seem less than the control firms it is seen that the leverage ratios of the manipulator firms are higher than the control firms. This increases the financial risk of the manipulators and makes them more fragile to interest and exchange rate shocks. However, the use of debt at a high rate may have been preferred because financing costs have led to higher profit per share due to the tax advantage. In terms of sales growth rate, it is observed that manipulator firms perform far behind the control firms.

The financial manipulation techniques performed by the companies included in the sample during the analysis period of 2010 - 2015 are summarized in the following table 8 and table 9 based on Küçüksözen's (2004) classification:

Table 8: Period Profit Increasing Techniques

\section{I - The Type of Technique Used}

No of Observations

None or underrecognition of Depreciation and amortization expenses. 3

Manipulation related to provisions for advance payments.

Excluding some subsidiaries from consolidation. 1

None or underrecognition of provision amount for losses.

Unconfirmed debt and receivable amounts.

Accrual processing for a revenue item that is not precisely known to be accurate.

None or miscalculation of deferred tax asset item.

None or underrecognition of provision amount related to legal penalties.

None or miscalculation of the provision for doubtful receivables from related and unrelated parties.

Recognition of consignment sales as sales in the income statement.

Reflecting interest on loans and exchange rates as asset items to the balance sheet.

Displaying Brand Value in the balance sheet.

Overvaluation of existing assets.

3

GRAND TOTAL

Table 9: Period Profit Reducing Techniques

II - The Type of Technique Used

Non or miscalculation of deferred tax asset item.

Related Party Transactions and Implicit / Camouflaged capital transactions

Related Party Transactions and Implicit/Camouflaged capital transactions - Providing funds to group companies at lower interest rates than their peers.

Causing to lose for the company by making pricing for the benefit of its related parties.

The loss of the company due to the share transfer agreements made by related companies.

GRAND TOTAL

While $89 \%$ of the manipulative transactions performed by the companies constitute transactions to increase the period profit, $11 \%$ constitute transactions aiming to decrease the period profit. Transactions conducted to increase the period profit are operations aimed to increase the credibility of the company for its partners include the customers, financial institutions, investors and funds etc. and these are usually designed to provide cheap funds to the firm. During the analysis 
period, the most performed ones were respectively; none-recognition or inadequate of provision for doubtful receivables from related or unrelated parties, mistakes made in the calculations related to deferred tax and impairment provision items. Transactions aimed to reduce the period profit are generally carried out in order to decrease company's tax liability. The vast majority of these transactions consist of mistakes made in calculations related to deferred tax assets and implicit capital transfers.

The Beneish model will be applied to measure whether firms that make seasoned equity offerings apply earnings management practices. There are two main reasons for choosing the Beneish model. (Küçüksözen, 2004: 291) :

- In addition to the analysis of accruals included in the financial statements, this model also considered financial ratios as independent variables in the calculations,

- Beneish model allow making analysis for the two years. Because each company in our sample has a different issue year, financial statements were analyzed under the three-year section are respectively pre-issuance year, issuance year and post-issuance year through the Beneish Model.

There are two types of errors may be encountered in the Beneish model: (Beneish, 1999 : 16)

Error Type 1 : Manipulator firm may be regarded as a company that does not perform financial manipulation.

Error Type 2: Designation of the sample firms as manipulator even if they do not make or apply.

Investors are likely to suffer losses if they encounter both of these types of errors, which described in Beneish model. In error type 1, investors will lose due to the purchasing stocks of firms which are manipulator indeed. Therefore, it is very clear that they will lose as firm's real operating performance come out. In the error type 2, the investors do not make the loss when they perceive firms as a manipulator, which are not indeed, but they will not tend to buy their shares. This means investors will miss chance to buy shares of companies that are not manipulator and carry potential high returns based on their financial performance. Loss of investors are defined as the opportunity cost in case of the increase in stock prices of firms that are perceived as manipulator. As a result, the loss caused by the Error Type 1 will be higher and the this type of error will be more important for the investors (Beneish, $1999: 16$ ).

The following model of Beneish (1999) has been applied to firms performed seasoned equity offerings by using the financial data of 2010, which is the first year of the analysis period:

$$
\begin{aligned}
& M_{i}=\beta X_{i}+\epsilon_{i} \\
& \text { The definition of the terms in the formula is shown below: } \\
& M_{i} \text { : Dependent Variable, } \\
& X_{i} \text { : Independent Variable, } \\
& B \text { : Coefficients of independent variables } \\
& \epsilon_{i} \text { : Error term }
\end{aligned}
$$

Probit analysis was performed using the independent variables in the model. Dependent variables are considered as 1 for the manipulator firms and 0 for the controller firms and the coefficients and error terms of the variables in the equation are calculated (Küçüksözen, 2004: 291).

As the independent variables included in the model, the variables of Küçüksözen's study published in 2004 were used. In this model, the variables included in the study of Beneish in 1999 were used. In addition, instead of the sale growth index of used in Beneish's study, inventories / net sales ratio and financing expenses / net sales ratio were used.

When considering that most of financial manipulation transactions are being made via the capitalization of financing expenses and inventory valuation methods in Turkey, in this study it has been accepted to add inventories / net sales ratio and financing expenses / net sales ratios to the model like in Küçüksözen's study.

The main explanatory variables used in the study and the formulas of these variables are shown below:

The trade receivables index reflects the change in the trade receivables of the company in the year of issuance compared to the previous year. An unexpectedly high increase in the index may be perceived as a sign of the possibility of financial manipulation by the firm. Under normal circumstances, the company has a sales policy according to its customer portfolio and product tree. Under this policy, it is certain how much of the company sales will be carried out as advance sales and the average term and interest rates are determined in credit sales.

If there is no radical change in the firm's operations, it is not expected that the sales policy will change at least in the short run. Therefore, a significant increase in this index compared to last year can be interpreted as financial manipulation in which the firm has increased its sales and/or receivables in order to increase the period profit. The most common methods 
used to inflate the receivables and sales, as well as in our sample, include showing consignment sales as real sales and showing unconfirmed amounts of debts and receivables in the balance sheet.

$$
\operatorname{TRI}_{t}=\frac{\text { Trade Receivables }_{t} / \text { Net }_{\text {Sales }}}{\text { Trade Receivables }_{t-1} / \text { Net Sales }_{t-1}}
$$

The gross profit margin index shows the change in the gross profit in issuance year compared to the previous year. Decline in the index or becoming lower than 1 indicates that the gross profit of the company is narrowing. Gross profit is described as a difference that is calculated by subtracting costs that are incurred to accomplish sales from net sales amount. It is one of the most important criteria of the sustainability of the company together with operating profit. It is possible to interpret this decrease as the firm can not generate sustainable cash flow in the medium and long term.

$$
G M I_{t}=\frac{\text { Gross Profit Margin }_{t} / \text { Net Sales }_{t}}{\text { Gross Profit Margin }_{t-1} / \text { Net Sales }_{t-1}}
$$

The asset quality index refers to the change in the value of other fixed assets held by the firm in the year of issue compared to the previous year. The reason for taking other fixed assets as a base is that most of the manipulative transactions are performed through capitalization of expenses amount of items related to this group rather than reflecting to the income statement as period expenses or loss.

$$
A Q I_{t}=\frac{\left(1-\text { Current Assets }_{t}+\text { Fixed Assets }_{t}\right) / \text { Total Assets }_{t}}{\left(1-\text { Current Assets }_{t-1}+\text { Fixed Assets }_{t-1}\right) / \text { Total Asset }_{t-1}}
$$

The depreciation index shows the change in the depreciation in issuing year compared to the previous year. Beneish (1999) calculated the depreciation rate as depreciation / depreciation plus net tangible assets. Küçüksözen (2004), because he could not obtain depreciation expense amount from balance sheet directly, he considered the depreciation expense as the difference between the tangible fixed assets of two periods. Since the depreciation expenses of each periods can be obtained directly from financial statements prepared based on International Financial Reporting Standards (IFRS) for the period 2010-2015, we did not need to make calculations to reach depreciation figures. If index becomes less than 1 this indicates that the firm may have carried out financial manipulation by changing the calculation method or increasing the useful life of the asset to show a higher period profit.

$$
A I_{t}=\frac{\left(\frac{\text { Change in Accumulated Depreciation }_{t}}{\text { Change in Accumulated Depreciation }_{t}+{\text { Tangible } \text { Assets }_{t}}_{t}}\right)}{\left(\frac{\text { Change in Accumulated Depreciation }_{t-1}}{\text { Change in Accumulated Depreciation }_{t-1}+\text { Tangible Asset }_{t-1}}\right)}
$$

Marketing, sales, distribution and general administrative index; Beneish (1999), in his model accepted that marketing and general administrative expenses are related to sales and disproportionate increase in this relation should be considered as negative about company's future expectations by the financial analyst. A firm with this profile can be expected to be more inclined to financial manipulation. Küçüksözen (2004) states that if this index is subject to high increase, it indicates that except for efficiency in company's operations, this also shows that company may apply financial manipulation by inflating its sales or reducing its expenses.

(Marketing, Selling and Distribution Expenses $s_{t}$ + General Administrative Expenses E $^{\text {) }}$

$$
\begin{aligned}
\text { MSA }_{t}= & \frac{\text { Net Sales }_{t}}{\left(\begin{array}{c}
\text { (Marketing, Selling and Distribution Expenses } \\
t-1
\end{array}\right.} \\
& \left.\quad+\text { General Administrative Expenses }_{t-1}\right)
\end{aligned}
$$

$$
\text { Net } \text { Sales }_{t-1}
$$


The change in the liabilities structure indicates the change in the company's leverage level. This index shows a change in firm's leverage level in issuing year compared to previous year. If index increases sharply or exceed 1 refers to company's increased financial risk. In case of increased financial risk, firm management can offset bank loans with buyers or expense accounts in order to avoid existing and potential investors having a negative perception about the firm (Küçüksözen, 2004 : 308).

$$
L_{V G I}=\frac{\left(\frac{\text { Short Term Liabilities }_{t}+\text { Long Term Liabilities }_{t}}{\text { Total Assets }_{t}}\right)}{\left(\frac{\text { Short Term Liabilities }_{t-1}+\text { Long Term Liabilities }_{t-1}}{\text { Total Assets }_{t-1}}\right)}
$$

The ratio of total accruals to total assets index; much of the studies on financial manipulation focuse on manipulative transactions through the using accruals. According to the principle of based on accrual recording method, income and expenses are recorded when they occurred rather than when they are piad or collected. Therefore, firms may want to show the current period profit as higher or lower by using these non-cash transactions. Total accruals are calculated as the change in operating capital excluding cash and depreciation. The purpose of using this index is to explain the relationship between the exchange of the firm's non-cash capital and financial manipulation. (Küçüksözen, 2004 : 309).

$$
\operatorname{TATA}_{t}=\frac{\begin{array}{c}
\left(\text { Current Assets }_{t}-\text { Cash and Cash Equivalent }_{t}-\right. \\
\left.\left(\text { Short Term Liabilities }_{t}-{\text { Principal Installments And Interests of Long }- \text { Term Liabilities }_{t}-}_{\text {Taxes Payable And Other Fiscal Liabilities }}\right)-\text { Amortisation Expenses }_{t}\right)
\end{array}}{\text { Total Assets }_{t}}
$$

Inventories / Sales ratios and Financing Expenses / Sales ratios were not included in Beneish (1999) but used in Küçüksözen (2004) model. The reason for considering these ratios as variables in our model is that in many manipulative transactions are being made through the usage of the inventories and financing expenses (Küçüksözen, $2004: 309-310$ ). The financial data set used in our study consists of the financial statements prepared according to IFRS through independent auditing of the companies. In income statement, which is one of these tables, because of the gross sales item is not used therefore in the calculations net sales item will be included as sale amount information.

The ratio of inventories to net sales index indicates change in inventories ratio in issuing year compared to previous year. In particular, firms may tend to show lower or higher profits for the current period by changing inventory valuation methods and by classifying general production costs under the cost of goods sold and inventories via the various type of methods (Küçüksözen, 2004 : 309). The increase in this index indicates that the share of inventories increases faster than sales. This ratio shows that firms can apply for financial manipulation in order to show the cost of goods sold low and presenting high period profit.

$$
I C R_{t}=\frac{\text { Inventories }_{t} / \text { Net }_{\text {Sales }}}{\text { Inventories }_{t-1} / \text { Net Sales }_{t-1}}
$$

The ratio of financing expenses to net sales; this index represents the change in the ratio in issuing year compared to the previous year. In case of being lower than 1 , this can be perceived as a sign of financial manipulation that the firm has made by capitalization of financing expenses under the cost of assets purchased or under the production costs in order to show the higher period profit. In the opposite case, the firm may perform the manipulation for reducing the period profit by showing financing expenses in the income statement as the deduction item from profit.

$$
\text { FSR }_{t}=\frac{\text { Financing Expenses }_{t} / \text { Net Sales }_{t}}{\text { Financing Expenses }_{t-1} / \text { Net Sales }_{t-1}}
$$

Within the framework of the above-mentioned independent variables, the data of the manipulator and the control companies for the 2010-2015 period are analyzed. The central distribution characteristics are presented in Table 10. 
Table 10: Distribution Characteristics of Independent Variables for Manipulator and Control Companies

\begin{tabular}{|l|l|l|l|l|}
\cline { 2 - 5 } \multicolumn{2}{c|}{} & \multicolumn{2}{l|}{ Control Companies (21) } & \multicolumn{2}{l|}{ Manipulator Companies (20) } \\
\cline { 2 - 5 } \multicolumn{1}{c|}{} & Mean & Median & Mean & Median \\
\hline TRI $_{\boldsymbol{t}}$ & 1.36 & 1.05 & 1.60 & 0.88 \\
\hline $\boldsymbol{G M I}_{\boldsymbol{t}}$ & 1.36 & 0.98 & 2.69 & 0.97 \\
\hline $\boldsymbol{A Q I}_{\boldsymbol{t}}$ & 2.07 & 1.14 & 1.15 & 1.00 \\
\hline $\boldsymbol{A I}_{\boldsymbol{t}}$ & 11.67 & 0.36 & 3.17 & 0.56 \\
\hline $\boldsymbol{M S A}_{\boldsymbol{t}}$ & 1.04 & 0.95 & 1.22 & 1.01 \\
\hline $\boldsymbol{L V G I}_{\boldsymbol{t}}$ & 1.00 & 0.87 & 0.96 & 0.91 \\
\hline $\boldsymbol{T A T A}_{\boldsymbol{t}}$ & -0.05 & -0.03 & 0.07 & 0.04 \\
\hline $\boldsymbol{I C R}_{\boldsymbol{t}}$ & 1.36 & 1.11 & 1.20 & 0.99 \\
\hline FSR $_{\boldsymbol{t}}$ & 1.62 & 1.00 & 2.21 & 1.09 \\
\hline
\end{tabular}

According to the information presented in Table 10, as a consistent with findings of Beneish study (1999), the average TRI index is higher for manipulator companies than control firms. This can be interpreted as a signal that manipulator companies perform credit sales at a higher rate, recording consigned sales in the income statement under the sale revenue item or tend to increase their sales figures through counterfeit invoices.

The higher average of GMI observed in manipulator firms is consistent with Beneish study (1999). This is evidence that manipulator companies tend to show higher profit margins in their financials. This finding is consistent with the fact that the vast majority (89\%) of companies that are expressed as manipulators from sample firms use period profit increasing methods.

When the results are analyzed in terms of asset quality (AQ), consistent with the results of Beneish (1999), the asset quality of manipulator companies seems to be worse than control companies. This can be regarded as a demonstration of why manipulator companies approach to use manipulation way.

When the results of the table are evaluated in terms of amortization expense (AI), it is available to see that, on the contrary to Beneish (1999) study, manipulator companies do not manipulate financial information through depreciation when compared to control companies. It was observed that the depreciation costs of the control companies are much higher than the manipulator companies.

By analyzing the results presented in the table by ratio of sales to marketing, selling and general administrative expenses (MSA), it is determined that manipulator companies have a higher MSA than control companies, contrary to the findings of Beneish (1999). This presents evidence that manipulator companies tend to disclose lower profitability by showing more expenses.

In terms of the change in leverage structure (LVGI); unlike the findings of Beneish (1999), manipulator firms seem to finance their activities less by borrowing than control firms. In fact, this conclusion implies that the manipulator companies don't need to resort to this path.

Results related to total accruals / total assets ratio that shows the proportion of non-cash working capital in total assets reflect positive results observed for manipulator firms consistent with Beneish study while it reflects the negative results for the control firms. This implies that manipulator companies finance their working capital through shareholder equity and control firms prefer to finance working capital with debt.

In terms of the inventories to sales ratio (ICR), the results based on table indicate that manipulator companies seem to have a smaller inventory amount than to control companies. This implies that manipulator companies are operating with lower inventory levels. This may be due to the fact that the manipulator companies are relatively smaller companies. Since this variable is not included in the study of Beneish (1999), the comparison could not be conducted with that study. Finally, when the results of the table are analyzed in terms of the financing expenses to sales ratio (FSR), manipulator companies are seem to be at higher levels of financing costs compared to control companies. This means that manipulator companies are smaller and have higher access costs to financing. Since this variable is not included in the study of Beneish (1999), the comparison could not be conducted with that study. 


\section{FINDINGS and DISCUSSIONS}

\subsection{Probit Analysis}

In the analysis, 9 index defined above were used as independent variables while dummy variable that indicates whether firms are manipulators was used as dependent variable. Probit analysis was performed using Eviews 9.0 program and other analyzes were performed through SPSS 22 program. The analysis results are presented in Table 11.

Table 11: Probit Analysis Results Regarding Manipulator and Control Companies

\begin{tabular}{|c|c|c|c|c|}
\hline \multirow{3}{*}{$\begin{array}{l}\text { Method\#: } \\
\text { Obs.: } \\
\text { Variable }\end{array}$} & \multicolumn{4}{|c|}{ ML-Binary Probit } \\
\hline & \multicolumn{4}{|l|}{41} \\
\hline & Coef. & Std. Error & z stat. & Prob. \\
\hline Constant & -0.53 & 0.98 & -0.54 & 0.58 \\
\hline $\mathrm{TRI}_{\mathrm{t}}$ & 0.16 & 0.20 & 0.84 & 0.39 \\
\hline $\mathrm{GMI}_{\mathrm{t}}$ & 0.08 & 0.11 & 0.73 & 0.45 \\
\hline$A Q I_{t}$ & $-0.40 *$ & 0.23 & -1.76 & 0.07 \\
\hline $\mathrm{Al}_{\mathrm{t}}$ & -0.009 & 0.007 & -1.22 & 0.22 \\
\hline $\mathrm{MSA}_{\mathrm{t}}$ & 0.81 & 0.75 & 1.08 & 0.27 \\
\hline $\mathrm{LVGI}_{\mathrm{t}}$ & 0.80 & 0.79 & 1.01 & 0.30 \\
\hline TATA $_{t}$ & $3.05^{*}$ & 1.56 & 1.94 & 0.05 \\
\hline$I C R_{t}$ & $-0.99 *$ & 0.54 & -1.83 & 0.06 \\
\hline $\mathrm{FSR}_{\mathrm{t}}$ & 0.15 & 0.13 & 1.10 & 0.26 \\
\hline Mc Fadden R squared & 0.30 & \multicolumn{2}{|c|}{ Mean Dependent var } & 0.48 \\
\hline S.D. Dependent var & 0.50 & \multicolumn{2}{|c|}{ S.E. Of regression } & 0.46 \\
\hline AIC & 1.45 & \multicolumn{2}{|c|}{ Sum squared resid } & 6.64 \\
\hline SIC & 1.87 & \multicolumn{2}{|c|}{ Log likelihood } & -19.78 \\
\hline HQI & 1.60 & \multicolumn{2}{|l|}{ Deviance } & 39.57 \\
\hline Restr. Deviance & 56.81 & \multicolumn{2}{|c|}{ Restr. Log likelihood } & -28.40 \\
\hline LR stat. & 17.24 & \multicolumn{2}{|c|}{ Avg. Log likelihood } & -0.48 \\
\hline Prob. (LR stat.) & \multicolumn{3}{|l|}{0.04} & \\
\hline Obs with Dep:0 & \multicolumn{3}{|l|}{21} & \\
\hline Obs with Dep:1 & \multicolumn{3}{|l|}{20} & \\
\hline
\end{tabular}


Note: \#; *Convergence achieved after 5 iteration, QML (Huber/White) standard errors \& covariance. * and **; shows the related parameters are statistically significant at the $10 \%$ and $5 \%$ significance levels, respectively.

As shown in Table 11, the significance level of the model (McFadden R-squared) was 30\%. In the study of Beneish (1999), this rate calculated as $30 \%$. From point of this view, the explanatory power of the model can be regarded as enough. The probability of the model is 0.04 and the model is statistically significant $(p<0.05)$. Since the model is statistically significant, the comments on the variables will be reliable. The results of the robustness check test are shown in Table 12.

Table 12: The Robustness Check Test Results of Model

\begin{tabular}{|l|l|l|l|}
\hline \multirow{2}{*}{} & \multicolumn{3}{|l|}{ Estimated Equation } \\
\cline { 2 - 4 } & Dep=0 & Dep=1 & Total \\
\hline$P($ Dep=1) $\leq$ C & 14 & 5 & 19 \\
\hline$P($ Dep=1) C & 7 & 15 & 22 \\
\hline Total & 21 & 20 & 41 \\
\hline Correct & 14 & 15 & 29 \\
\hline \% Correct & 66.67 & 75.00 & 70.23 \\
\hline \% Incorrect & 33.33 & 25.00 & 19.51 \\
\hline
\end{tabular}

According to the findings represented in Table 12, the average accuracy value of the model is $70.23 \%$, and the estimated results have statistically acceptable level. When we look at the model's estimating power, non-manipulator companies are estimated with a $66.67 \%$ accuracy ratio while manipulator companies are estimated with a $75 \%$ accuracy ratio.

When the analysis results are evaluated based on independent variables shown in Table 11; the trade receivables index (TRI) has a positive coefficient (0.16) in line with the analysis results of Beneish (1999), but it is statistically insignificant. This situation does not allow for the decision whether an increase in incompatibility with sales has increased the likelihood of manipulating financial information. The finding also differs from Tekin's study conducted in 2017.

The Gross Profit Margin Index (GMI) has a positive coefficient (0.08), but this is not statistically significant either. Therefore, it can not be said that declining in this index whether increases the likelihood of manipulating financial information. The finding is also different from Tekin (2017) study but it consistent is with Beneish (1999) study.

The asset quality index (AQI) has a negative coefficient $(-0.40)$, which is statistically significant at the $90 \%$ confidence level. In other words, the increase in asset quality reduces the company's risk of financial manipulation. This is consistent with our theoretical expectations but it is incompatible with the work of Beneish (1999) and Tekin (2017).

The depreciation index (Al) has a negative coefficient $(-0.009)$, which is not statistically significant. Therefore, it cannot be claimed that declining in this index increases the likelihood of manipulating financial information. This is consistent with our theoretical expectations and with the work of Beneish (1999) but it is incompatible with Tekin (2017).

Because variables include marketing, selling and administrative expenses/sale ratio (MSA), leverage change index (LVGI) and financing expenses / sales ratio (FSR) are calculated as positive but statistically insignificant, it is not available to claim that change in these variables increases the likelihood of financial manipulation. Results related to MSA index are not consistent with Beneish (1999) and Tekin (2017) while results based on LVGI index is consistent with Tekin (2017) but not consistent with Beneish (1999). Similarly, findings belong to FSR index are not consistent with Tekin (2017).

The coefficient of the total accruals / total assets ratio (TATA) is positive (3.05) and is statistically significant at $90 \%$ confidence level. Increases in non-cash working capital have significantly increased the likelihood of financial manipulation. This result is consistent with the work of Beneish (1999) but differs from Tekin (2017).

The coefficient of inventories / net sales ratio (ICR) variable is negative (-0.99) and is statistically significant at $90 \%$ confidence level. This finding suggests that if this index increase possibility of financial manipulation will be reduced. Findings related to ICR are also consistent with Tekin (2017) study.

The explanatory power of the independent variables included in the model is summarized in Table 13. 
Table 13: Statistically Significant Independent Variables in Determining Whether Firms Apply to Financial Manipulation

Statistically Significant Independent Variables at 90\% Confidence Level

Asset Quality Index (AQI)

Total Accruals / Total Assets (TATA)

Inventories / Net Sales (ICR)

Based on findings shown in table 13, it can be inferred that AQI and ICR ratios may decrease the possibility of being manipulator firm while TATA increases the possibility of being manipulator firm.

\subsection{Testing of the Model's Reliability}

The power of the model was tested using the coefficients obtained from the probit analysis and for this purpose, the following equation was established.

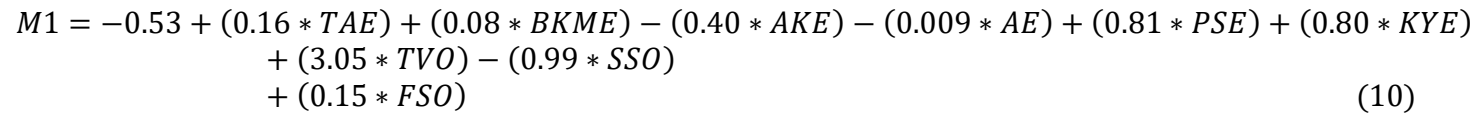

Using the firms' data for the t period in the equation (10), the possibility of being manipulator (M_i) was calculated for each firm included in the sample.

Table 14: Possibilities for Conducting Financial Manipulation by the Companies (Mi)

\begin{tabular}{|l|l||l|l|}
\hline FIRM & Mi & FIRM & Mi \\
\hline ACSEL & 0.51 & IHLAS & 0.14 \\
\hline AEFES & -0.62 & IZFAS & -0.16 \\
\hline AFYON & -0.20 & IZTAR & -1.06 \\
\hline AKENR & 0.82 & KARSN & 1.59 \\
\hline AKSEN & -0.21 & KERVT & 0.59 \\
\hline ALYAG & 2.47 & KIPA & 0.27 \\
\hline ARSAN & -0.88 & KRSTL & -0.74 \\
\hline ASLAN & -4.16 & MAKTK & 1.69 \\
\hline BAGFAS & 0.07 & METRO & -1.43 \\
\hline BALAT & 0.20 & MIPAZ & 0.58 \\
\hline BJKAS & -2.67 & NTHOL & 1.27 \\
\hline BISAS & 1.22 & ORMA & 0.45 \\
\hline BOYP & 0.57 & PIMAS & 0.18 \\
\hline BURVA & 0.79 & SAYAS & -1.05 \\
\hline CEMAS & 0.49 & TACTR & 1.09 \\
\hline DEVA & 0.41 & TBORG & -1.74 \\
\hline
\end{tabular}




\begin{tabular}{|l|l|l|l|} 
EDIP & -1.29 & TEKTU & -1.40 \\
\hline EGGUB & -0.36 & VANGD & -0.20 \\
\hline EMNIS & -0.39 & YATAS & 0.52 \\
\hline FRIGO & 0.01 & ZOREN & -1.52 \\
\hline GEREL & -0.62 & & \\
\hline
\end{tabular}

Kolmogorov-Smirnov and Shapiro-Wilk tests were used to determine whether the obtained M_i values has normal distribution. At this stage, the analysis was performed based on the study of Fındık and Öztürk (2016). Findings obtained in this test are shown in Table 15.

Table 15: Normality Test

\begin{tabular}{|l|l|l|l|l|l|l|}
\hline \multicolumn{4}{|l|}{ Kolmogorov-Smirnov ${ }^{a}$} & \multicolumn{3}{l|}{ Shapiro-Wilk } \\
\cline { 2 - 8 } & Statistic & $d f$ & Sig. & Statistic & Df & Sig. \\
\hline$M_{i}$ & 0.103 & 41 & $0.200^{*}$ & 0.954 & 41 & 0.099 \\
\hline
\end{tabular}

*. This is a lower bound of the true significance.

a. Lilliefors Significance Correction

In Table 15, it was decided that M_i values have normal distribution because the probability value is higher than 0,05 both in the Kolmogorov-Smirnov test $(0.20>0.05)$ and in the Shapiro-Wilk test $(0.09>0.05)$.

Because the values of $M_{-} i$ have normal distribution, the calculated values of $M_{-} i$;

$$
Z_{i}=\frac{M_{i}-\overline{\bar{M}}}{\sigma}
$$

can be converted to standard normal distribution value through this formula. In this formula, $M$ is the arithmetic mean of the values of $M_{-} i$ and $\sigma$ is the standard deviation of the values of $M_{-} i$. The standardized values of $M_{-} i\left(Z_{-} i\right)$ calculated by equation (11) are shown in Table 16.

Table 16: Standardized M_i (Z_i) Values

\begin{tabular}{|l|l|l|l|}
\hline FIRM & $z_{i}$ & FIRM & $z_{i}$ \\
\hline ACSEL & 0,51 & IHLAS & 0,21 \\
\hline AEFES & $-0,42$ & IZFAS & $-0,04$ \\
\hline AFYON & $-0,07$ & IZTAR & $-0,78$ \\
\hline AKENR & 0,77 & KARSN & 1,41 \\
\hline AKSEN & $-0,08$ & KERVT & 0,58 \\
\hline ALYAG & 2,13 & KIPA & 0,32 \\
\hline ARSAN & $-0,63$ & KRSTL & $-0,52$ \\
\hline ASLAN & $-3,33$ & MAKTK & 1,49 \\
\hline
\end{tabular}




\begin{tabular}{|l|l|l|l|}
\hline BAGFAS & 0,15 & METRO & $-1,08$ \\
\hline BALAT & 0,26 & MIPAZ & 0,57 \\
\hline BISAS & 1,10 & NTHOL & 1,14 \\
\hline BOYP & $-2,10$ & ORMA & 0,46 \\
\hline BURVA & 0,56 & PIMAS & 0,25 \\
\hline CEMAS & 0,74 & SAYAS & $-0,77$ \\
\hline DEVA & 0,50 & TACTR & 0,99 \\
\hline EDIP & 0,44 & TBORG & $-1,34$ \\
\hline EGGUB & $-0,97$ & TEKTU & $-1,06$ \\
\hline EMNIS & $-0,20$ & VANGD & $-0,07$ \\
\hline FRIGO & $-0,22$ & YATAS & 0,52 \\
\hline GEREL & 0,10 & ZOREN & $-1,15$ \\
\hline
\end{tabular}

The probability of manipulation Z_i values shown in Table 16 according to the normal distribution function was calculated by the K-Means Clustering analysis method. The $M_{-} i$ values obtained in this process are divided into three homogeneous groups. SPSS 22 program was used for cluster analysis. The clustering analysis results using Z_i value are given in Table 17.

Table 17: Initial Cluster Center

\begin{tabular}{|r|l|l|l|}
\hline \multicolumn{2}{|l|}{ Cluster } \\
\cline { 2 - 4 } & 1 & 2 & 3 \\
\hline$Z_{i}$ & -2.71 & -0.21 & 1.04 \\
\hline $\begin{array}{l}\text { The number of companies } \\
\text { included in this cluster. }\end{array}$ & 2 & 28 & 11 \\
\hline
\end{tabular}

According to the results in Table 17 if the $Z_{i}$ values are;

- $\quad Z_{i}<-2.71$, firms don't tend to manipulate their financials,

- $\quad-2.71 \leq Z_{i}<1.04$, tendency of firms to manipulation of financial statement is low,

- $1.04 \leq Z_{i}$, it was decided that the tendency of companies for manipulation is high.

Cluster and manipulation tendency of the companies subject to this analysis are presented in Table 18. 
Table 18: Breakdown of the Companies by Their Manipulation Tendency

\begin{tabular}{|l|l|l|}
\hline $\begin{array}{l}\text { No Tendency for } \\
\text { Manipulation }\end{array}$ & Low Manipulation Tendency & High Manipulation Tendency \\
\hline \hline ASLAN BJKAS & ACSEL AEFES AFYON & AKENR ALYAG BISAS \\
& AKSEN ARSAN BAGFAS & BOYP BURVA KARSN \\
& BALAT CEMAS DEVA & KERVT MAKTK MIPAZ \\
& EDIP EGGUB EMNIS & NTHOL TACTR \\
& FRIGO GEREL IHLAS & \\
& IZFAS IZTAR KIPA & \\
& KRSTL METRO ORMA & \\
& PIMAS SAYAS TBORG & \\
& TEKTU VANGD YATAS ZOREN & \\
\hline
\end{tabular}

At the beginning stage of the analysis, sample was divided into two categories as manipulator and control firms and 20 firms were regarded as companies with a high tendency to make manipulation. Through this analysis, 11 firms out of these 20 firms were confirmed in terms of manipulation. This indicates that the success rate in sample selection is $55 \%$.

The firms were grouped as firms with no or low tendency and a high tendency for manipulation. Average index values for the periods $t-1$, $t$ and $t+1$ were calculated for the companies included each group and the obtained data are presented in Table 19.

Table 19: Average Index Values of Companies with Low and High Manipulation Tendency

\begin{tabular}{|l|l|l|l|l|l|l|}
\hline & \multicolumn{2}{l}{$\begin{array}{l}\text { Companies } \\
\text { Manipulation Tendency }\end{array}$} & \multicolumn{2}{l}{$\begin{array}{l}\text { Wowith } \\
\text { Manipulation Tendency }\end{array}$} \\
\hline & Mean $t-1$ & Mean $_{t}$ & Mean $_{t+1}$ & Mean $_{t-1}$ & Mean $_{t}$ & Mean $_{t+1}$ \\
\hline TRI & 1.02 & 1.24 & 1.06 & 1.68 & 2.15 & 1.43 \\
\hline GMI & 1.27 & 1.32 & 1.06 & 0.98 & 3.90 & 0.62 \\
\hline AQI & 1.94 & 1.88 & 0.91 & 1.34 & 0.94 & 1.99 \\
\hline AI & 2.78 & 9.24 & 0.67 & 0.79 & 2.86 & -1.87 \\
\hline MSA & 1.10 & 1.02 & 0.99 & 1.15 & 1.45 & 0.99 \\
\hline LVGI & 1.05 & 1.02 & 1.00 & 1.10 & 0.87 & 1.11 \\
\hline TATA & -0.01 & -0.04 & 0.03 & -0.11 & 0.13 & -0.09 \\
\hline ICR & 1.02 & 1.27 & 1.06 & 1.30 & 1.33 & 1.48 \\
\hline FSR & 1.08 & 1.42 & 3.12 & 1.14 & 3.24 & 0.85 \\
\hline
\end{tabular}

When the data in Table 19 are examined in terms of TRI index, it can be accepted that all firms are manipulating. Because the TRI values of all firms at time $t$ (the year they perform seasoned equity offering) are higher than their previous and next year values. Similarly, based on GMI index values, it was determined that the value of GMI in the period in which the seasoned equity offering was abnormally higher than the other years. The AQI index tends to fall in firms that do not manipulate, while in manipulator firms it appears that it has been significantly lowered in the year the manipulation made. It has been observed that $\mathrm{Al}$ index is rising extremely in all firms performed seasoned equity offerings and this increase is higher than in firms with low tendency of manipulation. It was observed that MSA value tends to fall over time in firms with a low tendency for manipulation. But for the firms that have a high tendency to manipulate, it increased at the time of seasoned equity offering but then fell in the following years. It was determined that LVGI value tends to fall over time in firms with a low tendency for manipulation while for the firms that have a high tendency to manipulate, first, it decreased at the time of issue but then fell in the next year. TATA value reduced at the time of issue but in next year it starts to increase for firms with a low tendency for manipulation and in firms have a high tendency to manipulate, it increased in issue period then starts to fall. It was determined that the value of ICR increased in the issuing year when they performed seasoned equity offering by the firms with low propensity to manipulate and decreased in the following year, it also increased continuously in firms with high tendency to manipulate. Finally, FSR value tends to increase constantly in firms with low propensity to manipulate, while in firms with a high tendency to manipulate, it tends to increase in the year they perform the issuance and decrease again in the following year.

The Paired Sample Statistics $t$ test was used to test whether there is a significant difference between firms in high and low propensity for manipulation in terms of the index values for the period $t+1$ (the period after manipulation). This test is effective in testing whether a group's measurements of two different qualities are different (Akdag, 2011). The purpose of 
this analysis is to test whether the behavior of manipulator companies significantly differentiate financial data compared to non-manipulator. The test results are presented in Table 20.

Table 20: Paired Samples Test

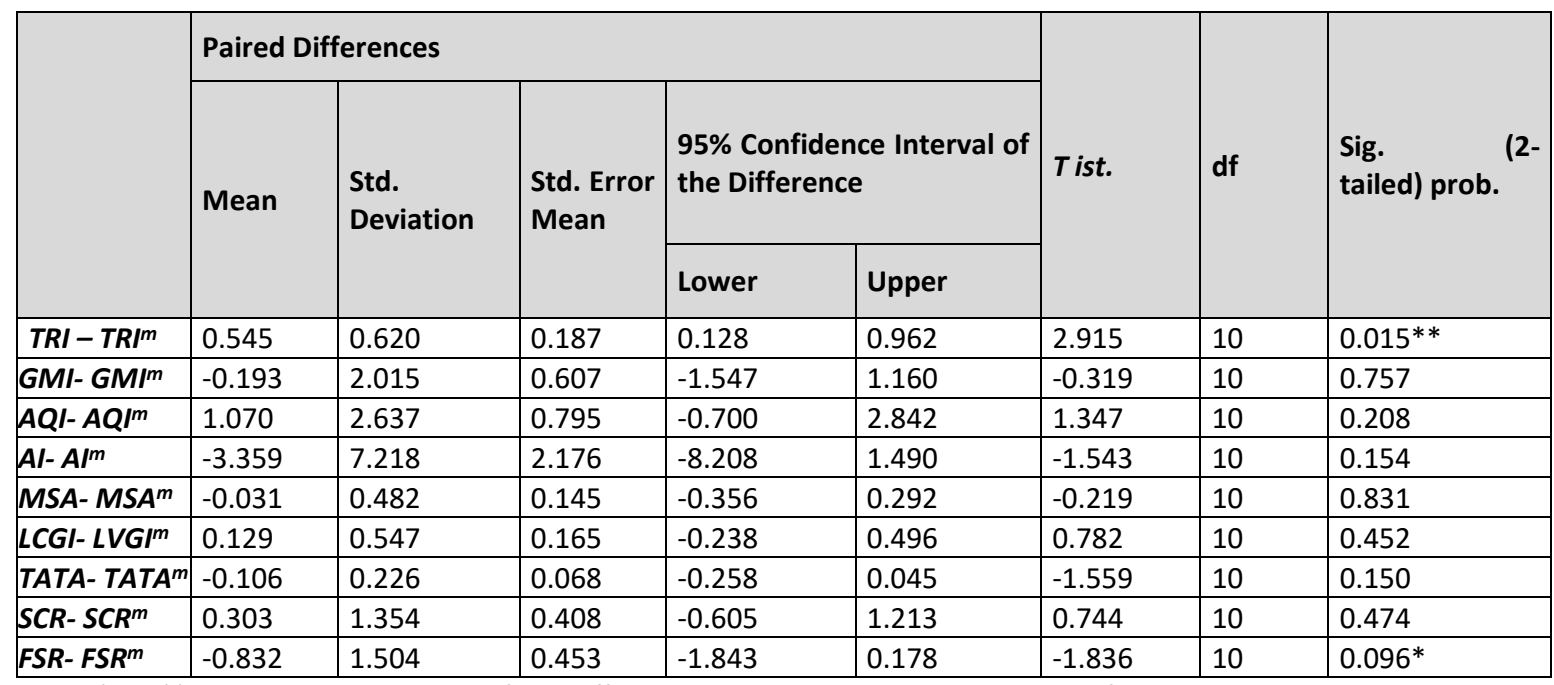

Note: ${ }^{*}$ and ${ }^{* *}$ suggest that there is a significant difference between groups at $10 \%$ and $5 \%$ significance level respectively.

Table 20 shows that there is a significant difference between the manipulator and non-manipulator companies based on the value of TRI and FSR. Based on these findings, it can be inferred that firms with a high propensity, performed the manipulative transactions through these variables.

\section{CONCLUSION}

Many studies in the literature show that firms may manipulate their financials before seasoned equity offerings in order to maksimize their issue revenue. For the purpose of misleading current and potential investors they may apply some tecniques include period profit increasing techniques, period profit decreasing techniques and other techniques. All these mentioned techniques are conducted through earning management, income smoothing and creative accountings methods.

In this study, we tried to find out wheter sample firms that perform seo during the $2010-2015$ period in Borsa Istanbul may apply financial mnaiupulation. For this purpose, we divided sample into 2 sections as manipulator firms and control firms through observations based on reports and bulletins of regulator institutions such as Borsa Istanbul and Capital Market Board. Then we used 9 financial ratios were defined both in Beneish's study (1999) and Küçüksözen's study (2004) as independent variables in the model. Probit analysis was conducted to see effects of all these independent variables on determining wheter firms apply manipulation or not. Then we made robust tests and calculated possibility of manipulation for each firm in the sample. We performed cluster analysis to see tendency of all firms for the manipulation and we grouped all firms as high and low tendency for manipulation based on average index values.

In this study, we figure it out firms may apply financial manipulation before seos in order to increase issue revenue. We observed that most of manipulations were performed through period profit increasing techniques. Approiximately $\% 90$ of manipulation tehcniques were constitute period increasing methods. Underrecognition of provision for doubtful receivables from related and unrelated parties, miscalculation of deferred tax expenses, underrecognition of losses and amortization expenses, showing brand value in the balance sheet and finally recognition of consignment sales as real sales in the income statement are most frequently used methods among the period profit increasing techniques.

In the model, three financial ratios include Asset Quality Index, Inventories / Sales, Total Accruals / Total Assets were found statistically significiant on determining wheter firms may make manipulation. In other words, we found that sample firms use these three variables in order to make manipulation. According to previous studies in the litetature, accruals particularly discreationary accruals and inventories are the most subject to financial manipulation. Therefore, our findings are consistent with the previous literature. Our model's average estimating power was calculated as $\% 70,23$. We predicted manipulator and control firms with $\% 75$ and \%66,67 accuracy ratio respectively. According to model's reliability test 11 firms were found as have high manipulation tendency. Considering 20 firms were defined as manipulators at the initial step of the study based on observations it is possible to say that our model's success rate for estimating manipulator firms is $\% 55$. 


\section{REFERENCES}

ACFE. (2010). Report to the nation on occupational fraud and abuse. The Association of Certified Fraud Examiners

Acharya, V. V., Lambrecht, B. M. (2015). A Theory of Income Smoothing When Insiders Know More Than Outsiders. The Review of Financial Studies, 28 (9): 2534-2574.

AICPA. (2002). Consideration of fraud in a financial statement audit. $1719-1770$.

Akdağ, M. (2011). SPSS'de istatistiksel analizler. https://cms.inonu.edu.tr /uploads/old/5/1328/spss-testleri.doc. [Erişim Tarihi: 09.08.2017].

Beneish, D. M. (1997). Detecting GAAP violation: implications for assessing earnings management among firms with extreme financial performance. Journal of Accounting and Public Policy. 16 (3): 271-309.

Beneish, D. M. (1999). The detection of earnings manipulation. Financial Analyst Journal. 55 (5): 24-26.

Shu, P. G., Chiang, S. J. (2014). Firm size, timing and earnings management of seasoned equity offerings. International Review of Economics \& Finance. 29 (1): 177-194

Beneish, D. M. (2001). Earnings management: a perspective. Managerial Finance. 27 (12): 3-17.

Çelik, I. E. (2016). The relationship between accounting practices and effects of financial crisis in Turkey: a case study on an oil company. Emerging Markets Journal. 6 (1): 47-58.

Deangelo, L. E. (1986). Accounting numbers as market valuation substitutes: a study of management buyouts of public stockholders. The Accounting Review. 61 (3): 400-420.

Fang, C. (2017). Empirical research on accrual and real earnings management: evidence from seasoned equity offerings. Proceedings of the 14th International Conference on Innovation \& Management, 1121-1126.

Fındık, H., Öztürk, E. (2016). Measurement of financial information manipulation with the help of Beneish Model: a research on BIST manufacturing industry. Journal of Business Research Turk. 8(1): 483-499.

Healy, P. M. (1985). The effect of bonus schemes on accounting decisions. Journal of Accounting and Economics. 7 (1-3): 85-107.

Islam, M. S., Uddin, M., Ahmad, S. (2002). The operating performance of firms conducting seasoned equity offerings In Bangladesh. Journal of Business Studies. 23 (2): 1-42.

Jo, H., Kim, Y. (2008). Ethics and disclosure: a study of the financial performance of firms in the seasoned equity offerings market. Journal of Business Ethics. 80 (4): 855-878.

Jones, J. (1991). Earnings management during import relief investigations. Journal of Accounting Research. 29 (2): 193 - 228.

Kothari, S. P., Mizik, N., Roychowdhury, S. (2016). Managing for the moment: the role of earnings management via real activities versus accruals in SEO valuation. American Accounting Association. 91 (2) : 559-586.

Küçüksözen, C. (2004). Finansal bilgi manipülasyonu: nedenleri, yöntemleri, amaçları, teknikleri, sonuçları ve İmkb şirketleri üzerine ampirik bir çalışma. Doktora Tezi, Ankara Üniversitesi, Sosyal Bilimler Enstitüsü.

Li, S., Richie, N. (2016). Income smoothing and the cost of debt. China Journal Accounting Research. 9 (3): 175 - 190.

Mulford, W. C., Comiskey., E. E. (2002). The financial numbers game - detecting creative accounting practices. New York: John Wiley \& Sons Inc.

Rezaee, Z. (2005). Causes, consequences and deterence of financial statament fraud. Critical Perpectives on Accounting. 16 (3) : 277 - 298.

Spathis, C. T. (2002). Detecting false financial statements using published data: some evidence from Greece. Managerial Auditing Journal, $17(4): 179-191$.

Tassadaq, F., Malik, A. Q. (2015). Creative accounting and financial reporting: model development and emprical testing. International Journal of Economics and Financial Issues. 5 (2): 544-551.

Tekin, E. (2017). 2010-2014 yılları arasında Türkiye'de halka açık şirketlerde manipülasyon üzerine Beneish Modeli ile ampirik çalışma. Yayınlanmamış Doktora Tezi, Başkent Üniversitesi, Sosyal Bilimler Enstitüsü İşletme Anabilim Dalı Muhasebe - Finansman Bölümü.

Teoh, S. H., Welch, I., Wong, T. J. (1998). Earnings management and the underperformance of seasoned equity offerings. Journal of Financial Economics. 50 (1): 63 - 99.

Ulusan, H. (2008). Değerleme esasları ve finansal tabloların niteliksel özellikleri açısından incelenmesi. Anadolu Üniversitesi Sosyal Bilimler Dergisi. 8 (1): 129-154.

Zhang, X. (2016). Income smoothing, idiosyncratic risk \& CEO turnover. Journal of Mathematical Finance. 6 (1): 1 - 16. 